\title{
The Relationship Between EFL Learners' Satisfaction Within the Classroom Environment and Their Speaking Skills
}

\author{
Maysa M. Qutob ${ }^{1}$ \\ ${ }^{1}$ English Language Institute, King Abdulaziz University, Jeddah, Saudi Arabia \\ Correspondence: Maysa M. Qutob, English Language Institute, King Abdulaziz University, Jeddah, Saudi \\ Arabia. E-mail: mqutob0001@stu.kau.edu.sa
}

Received: May 15, 2018 Accepted: June 14, 2018 Online Published: June 16, 2018

doi: $10.5539 /$ elt.v11n7p116 URL: http://doi.org/10.5539/elt.v11n7p116

\begin{abstract}
This study investigates EFL students' satisfaction with their acquired speaking skills based on the materials used as part of the classroom environment, and the teacher as a facilitator of the classroom environment. A questionnaire was adapted from Asakereh and Maliheh's (2015) study, and completed by 60 students in the tenth grade at a private school in Jeddah. The study's findings reveal that students are highly satisfied with their acquired speaking skills, materials, and language teacher. Moreover, a positive correlation was found between students acquired speaking skills with materials and with the language teacher.
\end{abstract}

Keywords: speaking skills, classroom environment, EFL students satisfaction

\section{Introduction}

The English as a foreign language (EFL) classroom is probably the only place for students in Jeddah to speak English, so the EFL class environment should be given significant care. Teachers take great care to prepare speaking class materials, such as activities and organizing the class setting to make the speaking environment student friendly. As a result, students are involved in the learning process, which increases satisfaction and sense of achievement. The current study addresses tenth grade EFL students' satisfaction with speaking skills in relation to language classroom materials used and the language teacher.

Previous studies, including those of Bergil (2016), Peng (2015), and Akdemir, Brain, and Demiroz (2012), have focused on EFL university students' perceptions of speaking skills regarding their willingness to communicate and the significant factors that create a more engaging classroom environment. To the best of my knowledge, no studies related to tenth grade EFL students, with an Arabic L1 background, have been undertaken to measure their satisfaction with speaking skills in relation to materials and teacher. Accordingly, I conducted this study to answer the following question: To what extent are tenth grade EFL learners satisfied with the classroom environment in relation to their speaking skills?

In this section, I discuss student satisfaction, speaking skills, and classroom environment, in relation to the research question. The review is based on the idea that examining students' satisfaction with acquired knowledge in class and the classroom environment reflects their achievement.

\subsection{Student Satisfaction}

Satisfaction, according to Oliver (1997), is a state of pleasure that one may perceive from achieving a desirable aim. EFL student satisfaction with learning outcomes and the teaching process is considered an important factor in generating the motivation for student performance (Wu, Marek, \& Yen, 2012; Rashidi \& Moghadam, 2014). Wu, Tennyson, and Hsia (2010) and Asakereh and Dehghannezhad (2015) argued that EFL student satisfaction is expressively affected by the learning environment. Moreover, Bolliger (2004), and Booker and Rebman (2005), Jones (2008) suggested that the support of the teacher influences students' satisfaction and increases their motivation to learn. In EFL classrooms, one of the skills practiced is speaking as a form of communication, according to Pishghadam, Zabetipour and Aminzade (2016), and EFL learners find speaking classes the most enjoyable. 


\subsection{Speaking Skills}

Speaking is a practice of interactions, which includes creating and receiving information to convey meaningful construction (Brown, 1994). In addition, speaking is one of the four main skills for EFL students and essential for communication. For this reason, EFL teachers strive to create an interactive environment to encourage students to speak. Nunan (1991) held that performing conversations efficiently in a language is a real achievement. Mahbub-ul-Alam and Khan (2014) argued that developing linguistic and sociolinguistic skills are necessary to learn a language, whether first or second; consequently, the more students acquire vocabulary, fluency and accuracy, the more they improve their speaking skills. Classrooms, then, are the main place for EFL students to conduct conversation and practice speaking because as Sim and Pop (2016) suggested, the daily language produced by speaking is more than can be produced by writing.

\subsection{Classroom Environment}

Wu, Tennyson, and Hsia (2010) defined classroom environment as the physical and social aspects of a classroom created and facilitated by the teacher. Many factors underline classroom environment to influence student learning regarding behaviour and performance. Peng (2015) examined university freshmen in China to identify the most significant factors of classroom environment, and concluded that English classes should represent a motivational environment including books and teaching methods.

Yet, Bergil (2016) conducted a quantitative-qualitative study of Turkish male and female university students by applying two kinds of scales: one scale completed by students to measure their willingness to communicate in speaking class; another scale completed by the teachers to measure student speaking achievements. Bergil (2016) concluded that student's failure to improve speaking skills is a direct result of the teacher's ability and material implemented in class.

Hence, it is the responsibility of language teachers to select appropriate materials for speaking classes, specifically in countries where only L1 is spoken. Akdemir, Barin, and Demiroz (2012) experimented with university students taking speaking courses and found evidence to show that speaking is best taught through authentic materials. Sim and Pop (2016) suggested that teachers should consider the age and level of the students when designing speaking activities, as it may affect student motivation and satisfaction. Moradi and Talebi (2014) also explored speaking classes and university students to conclude that teachers' selection of appropriate tasks to engage students to communicate effectively in the classroom created an interactive environment. Zahoor-ul-Haq, Khurram and Bangash (2017) studied sixth grade students and recommended activity-based instructions in speaking classes to enhance student speaking and to improve their achievement and thus. Finally, one study suggested using speaking activities based on sensory differences to promote students interest in speaking (Ghani, Nawaz, \& Asif, 2015).

To encourage students to interact within the classroom, teachers should implement different activities through group work. For example, Yurt and Aktas (2016) illustrated that peer tutoring in English speaking classes positively affects students speaking efficacy, in addition, students become highly satisfied. Moreover, Espinel and Canaría (2010) found that when students are engaged in cooperative learning, they are influenced by one another, which develops speaking social interactions.

Nash, Crimmins, and Oprescu's (2016) study on oral assessments and presentation, as part of the activities used in a university classroom, showed that it is crucial for teachers to assess speaking through class activities to create a natural environment for the students during assessments.

Previous studies covered material employed by teachers in EFL speaking classes, which enhance student efficacy and satisfaction in the learning process. Given the importance of student satisfaction in relation to speaking skills, the current study investigates the latter, which equates student satisfaction with the teaching process as part of the classroom environment. The study investigates $10^{\text {th }}$ grade with Arabic L1 backgrounds. The class teacher varies the speaking activities, implements group work, and assesses the students accordingly. I hypothesize that: (1) there is a significant positive correlation between acquired speaking skill and materials used; and (2) there is a significant positive correlation between acquired speaking skills and the instructor.

\section{Method}

\subsection{Participants}

The current study partially replicates that of Asakereh and Dehghannezhas' (2015) study that investigated university male and female students between the ages of 18 to 35, with a Persian L1 background, and taught by different teachers. Furthermore, they conducted two questionnaires on student satisfaction with speaking classes and speaking skills self-efficacy beliefs. To answer the research questions, a correlation between speaking skills 
with self-efficacy beliefs and student achievement was established. The current study investigates 60 female students from an Arabic L1 background, ages 15-16, studying EFL in grade 10 at a private school in Jeddah. The students were chosen randomly and equally from five classes. The participants' English proficiency varied: they were taught by one teacher and shared the same curriculum, books, and materials. The teacher has a bachelor's degree in English, with five years' teaching experience with an Arabic L1 background. Students take five EFL classes per week, where speaking is practised daily through a variety of speaking activities.

\subsection{Instruments}

A questionnaire form Asakereh and Dehghannezhad (2015) was modified to suit the students' ages and to correspond to the research objective. Item selection was based on the participants' ability to comprehend, tolerance to the length of the questionnaire, and adequacy for the collection of necessary data. The questionnaire has three main dimensions: acquired speaking skills, materials, and instructor. Additionally, the questionnaire consists of 15 items based on the Likert scale, beginning with very unsatisfied to very satisfied and approved by an expert in teaching English as a foreign language.

\subsection{Procedure}

The questionnaire was translated into Arabic and then converted for electronic use on Google Drive. It was administered in the schools' computer lab by a member of the school's administration department, who did not know the students, with the help of the information technology (IT) assistant who rearranged the computer lab. During substitution and activity classes, the administrator randomly selected twelve students and accompanied them to the computer lab, where the IT assistant assigned a computer to each participant to complete the questionnaire in approximately 5 minutes. After the required number of forms were completed, data was then organized in an Excel spreadsheet for statistical analysis using SPSS. The answers were then transferred to numbers, in a range from very unsatisfied $=1$ up to very satisfied $=5$.

\subsection{Analysis of Method}

SPSS 21.0 was used to extract Cronbach's alpha to ensure reliability. Validity was ensured by calculating internal consistency and examining the correlation between each individual item and the total score of the questionnaire. Then descriptive analyses were used to give estimates of student satisfaction on the questionnaire's three dimensions presented by the means, standard deviations, and frequencies. The Pearson's correlation coefficient was used to verify the study's hypotheses related to the relationship between speaking skills with material and the teacher.

\section{Results}

As the questionnaire is a five-point scale, items were given scores ranging from (1-5), where $5=$ strongly satisfied, and $1=$ strongly unsatisfied. The minimum possible score of the questionnaire is 15 , and the maximum is 75 .

\subsection{Validity and Reliability of the Questionnaire}

The questionnaire possesses a high level of reliability, Cronbach's alpha $=.94$. To obtain a measure of the items' validity, multiple correlations were performed between the items and the total scores of the questionnaire. Correlations scores ranged between .6 and .9 , and all correlations were significant at $p<.001$. Moreover, correlations between the dimensions and their items were performed, and all correlations ranged between .6 and .9 and were significant at $p<.001$. See Table 1 for the correlations between items and total scores.

\subsection{Satisfactory Levels}

Means and standard deviations were calculated for each dimension. Students showed roughly similar levels of satisfaction on all dimensions, with a slightly higher level of satisfaction with the instructor: satisfaction with instructor $(\mathrm{M}=3.83, \mathrm{SD}=.49)$, satisfaction with materials $(\mathrm{M}=3.47, \mathrm{SD}=1)$, and satisfaction with acquired speaking skills $(\mathrm{M}=3.8, \mathrm{SD}=.98)$. High levels of satisfaction with the instructor are reflected in the average scores of the items related to the instructor dimension: four of the six items obtained an average above 4. See Table 2 for means and standard deviations for each item in the scale.

Frequency of responses to each item in the questionnaire was calculated by collapsing the two positive answers in one category, and collapsing the two negative responses in one category, in addition to the neutral responses. Therefore, three categories are shown for each item: satisfied, neutral, and dissatisfied. See Figure 1 for percentage of responses to items of dimension 1 (satisfaction with acquired speaking skills), Figure 2 for dimension 2 (satisfaction with materials), and Figure 3 for dimension 3 (satisfaction with instructor). 
The highest level of satisfaction is with the instructor. Satisfied responses ranged between $61.7 \%$ and $87.3 \%$, while unsatisfied responses range between $8.3 \%$ and $16.7 \%$. Students show a high level of satisfaction with acquired speaking skills. Their satisfaction with all items related to this dimension ranged between $63.7 \%$ and $74 \%$. In contrast, unsatisfied responses ranged between $13.3 \%$ and $18.3 \%$. Last and least, materials show moderate levels of satisfaction. Positive responses ranged between $38.3 \%$ and $65 \%$. Although negative responses for most items ranged between $8.3 \%$ and $16.3 \%$, item 6 , which is related to the level of the textbook, received a high percentage of satisfaction, $48.3 \%$.

Table 1. Correlations for items with total score of dimension and total score of the questionnaire

\begin{tabular}{|c|c|c|c|c|c|}
\hline & & $\begin{array}{l}\text { Correlations with the } \\
\text { Score }\end{array}$ & Dimension & $\begin{array}{l}\text { Correlations with th } \\
\text { Score }\end{array}$ & Total \\
\hline Dimensions & Items & Pearson's Correlation & Sig & Pearson's Correlation & Sig \\
\hline \multirow{4}{*}{$\begin{array}{l}\text { Satisfaction with acquired } \\
\text { speaking skills }\end{array}$} & 1 & 0.83 & 0.001 & 0.82 & 0.001 \\
\hline & 2 & 0.82 & 0.001 & 0.61 & 0.001 \\
\hline & 3 & 0.9 & 0.001 & 0.68 & 0.001 \\
\hline & 4 & 0.85 & 0.001 & 0.77 & 0.001 \\
\hline \multirow{4}{*}{ Satisfaction with materials } & 5 & 0.77 & 0.001 & 0.001 & 0.001 \\
\hline & 6 & 0.67 & 0.001 & 0.46 & 0.001 \\
\hline & 7 & 0.86 & 0.001 & 0.77 & 0.001 \\
\hline & 8 & 0.81 & 0.001 & 0.78 & 0.001 \\
\hline \multirow{7}{*}{ Satisfaction with instructor } & 9 & 0.87 & 0.001 & 0.87 & 0.001 \\
\hline & 10 & 0.85 & 0.001 & 0.78 & 0.001 \\
\hline & 11 & 0.92 & 0.001 & 0.78 & 0.001 \\
\hline & 12 & 0.85 & 0.001 & 0.72 & 0.001 \\
\hline & 13 & 0.67 & 0.001 & 0.65 & 0.001 \\
\hline & 14 & 0.8 & 0.001 & 0.7 & 0.001 \\
\hline & 15 & 0.87 & 0.001 & 0.76 & 0.001 \\
\hline
\end{tabular}

\subsection{Correlation Between Acquired Speaking Skills and Other Components}

To answer the question of whether a significant positive correlation exists between satisfaction with the two components of classroom environment and acquired speaking skills, two correlations were performed between acquired speaking skills and the two environmental components of materials and instructor. The correlation was significant at $p<.001$ for both correlations, $r=.69$ and $r=.65$, for correlation with materials and instructor, respectively.

Table 2. Means and standard deviations for each item

\begin{tabular}{lll}
\hline Items & Means & Standard Deviations \\
\hline Spoken vocabulary learned & 3.97 & 1.1 \\
Effect of class on pronunciation & 3.52 & 1.24 \\
Effect of class on your fluency & 3.88 & 1.1 \\
Use of learned material for real life communication & 3.83 & 1.21 \\
Class provides speaking among classmates and instructors & 3.82 & 0.96 \\
Level of course book & 2.86 & 0.97 \\
Improvement of weaknesses & 3.46 & 1.39 \\
Speaking activities & 3.63 & 1.25 \\
Topic presented in class for discussion & 3.58 & 1.14 \\
\hline
\end{tabular}




\begin{tabular}{lll}
\hline Instructor's motivation for teaching & 4.12 & 1.25 \\
Instructor's support & 4.07 & 1.26 \\
Method of evaluation & 4.13 & 1.05 \\
Audio-visual facilities in class & 3.63 & 1.28 \\
Instructor's feedback on mistakes & 4.08 & 1.28 \\
Encouragement of instructor & 4.23 & 1.47 \\
\hline
\end{tabular}

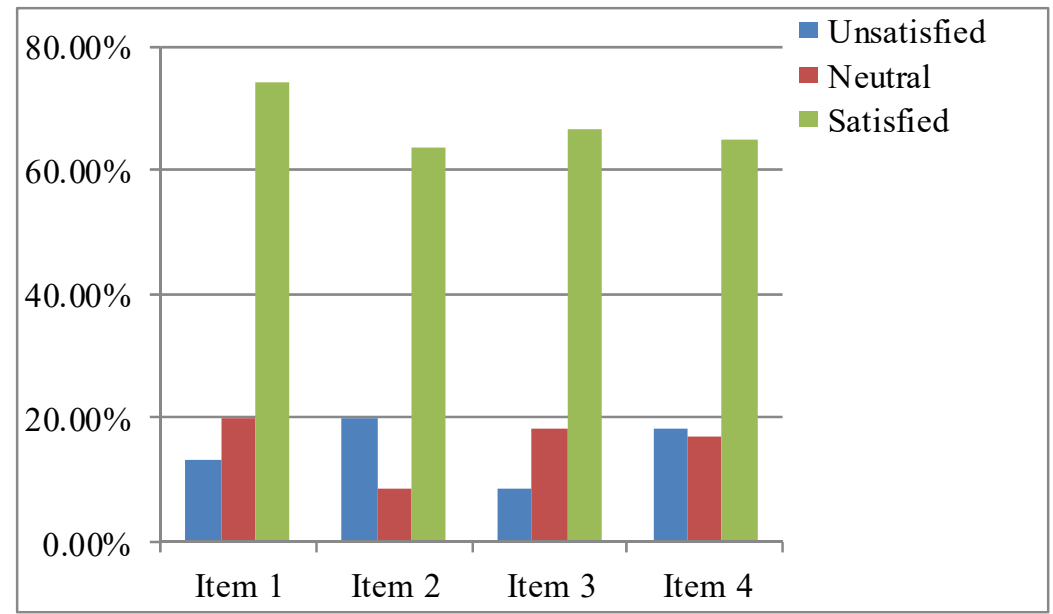

Figure 1. Frequency of responses, of the four items related to acquired speaking skills

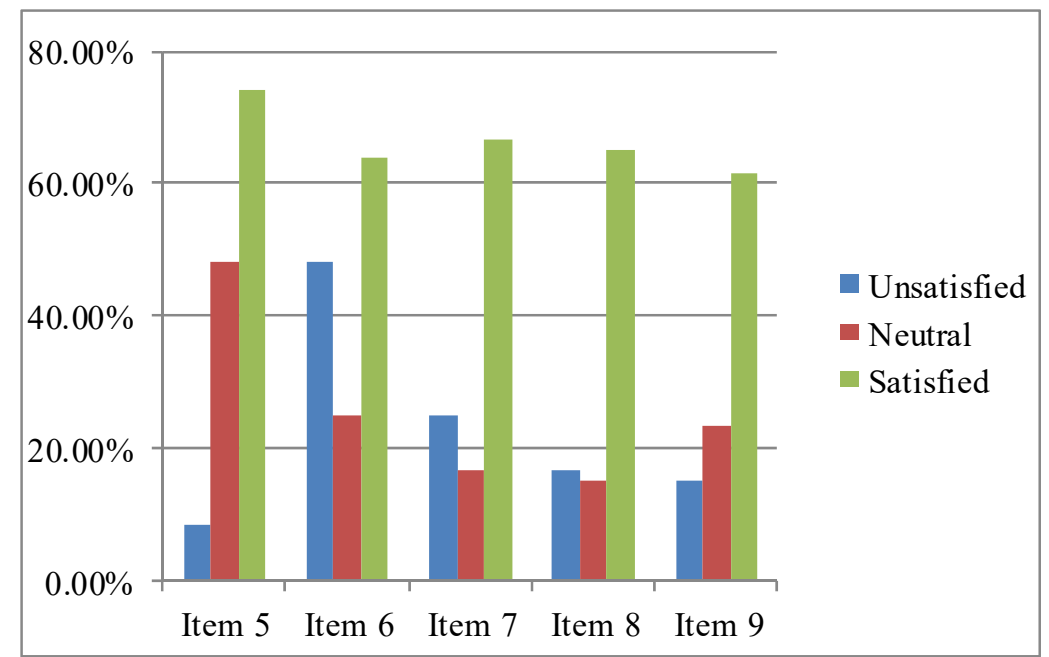

Figure 2. Frequency of responses to the five items related to materials 


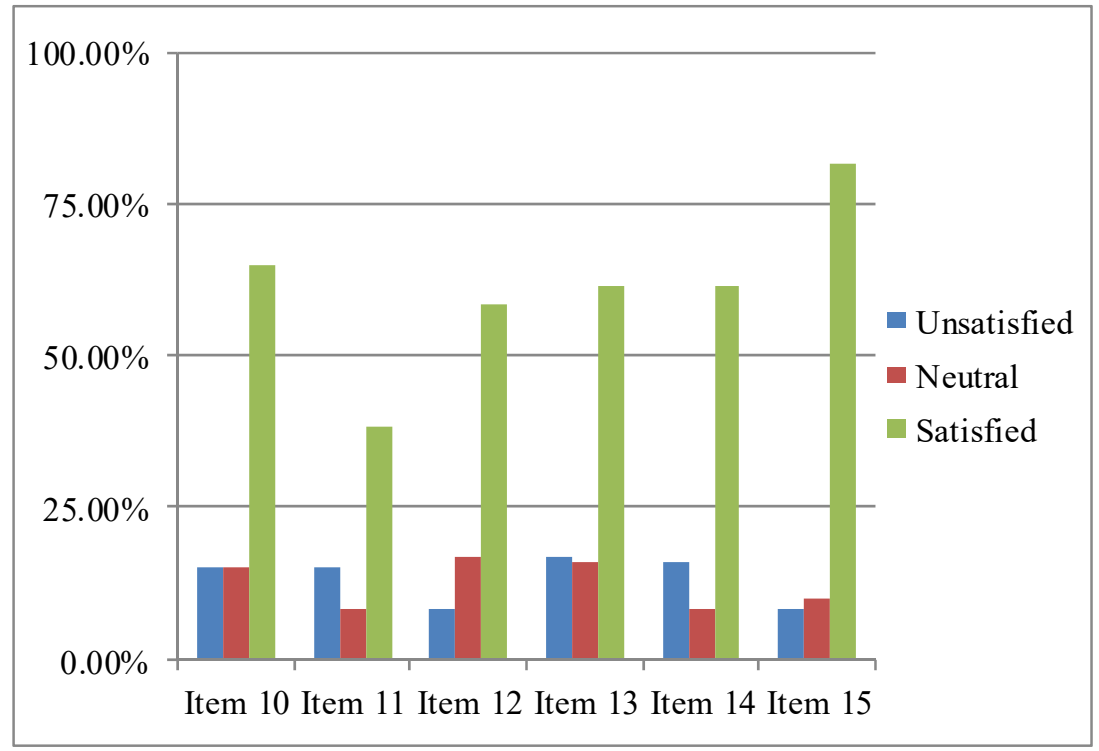

Figure 3. Frequency of responses to the six items related to instructor

\section{Discussion}

The current study investigates EFL students' satisfaction with acquired speaking skills, material provided as part of the classroom environment, and the teacher as a facilitator of the teaching process. The findings indicate that the students are highly satisfied with their speaking, materials, and teacher. Moreover, there is a positive correlation between the students acquired speaking skills and classroom materials, and a significant correlation between students' speaking skills and the teacher.

According to the items related to acquired speaking skills, students are most satisfied with their vocabulary, which they practice and learn in class. They also think that speaking classes provide a suitable environment to interact with their classmates and teacher. Moreover, the results indicate that the students, among all items related to the teacher, held the view the teacher creates an appropriate environment for speaking, and gave significant encouragement. Thus, and as Rashidi and Moghadam (2014) found, when students are satisfied, they achieve at higher rates.

Student satisfaction is a necessary factor in measuring the teaching environment from the students' point of view, which promotes their willingness to learn. Thus, students' perception of the teacher and environment affects their performance. The results show that students are highly satisfied with speaking skills acquired from their EFL class, which may positively impact their achievements. As mentioned in the previous section, Bergil (2016) reported similar results to the current study: students' achievements are affected by the quality of teacher and classroom environment. Similarly, Asakereh and Dehghannezhad (2015) also noted a significant relation between student satisfaction with speaking skills and self-proficiency.

The results show a connection between student satisfaction with their performance and their EFL teacher. Furthermore, the results reflected student satisfaction with the EFL teacher's role in the class to support, encourage, and correct. Bolliger (2004) and Booker and Rebman (2005) indicated that teachers are one of the most significant influences on student satisfaction. Additionally, Booker and Rebman (2005) also argued that the efficiency of the teacher is a main cause of students' demotivation and the decrease in levels of satisfaction.

The results also illustrated a relation between speaking skills acquired and classroom environment for materials, which matches Asakereh and Dhghannezhad's (2015) results for the questionnaire, from which the current study's questionnaire was adapted. The current study's findings also agree with those of Peng (2015) and Bergil (2016): students acquired speaking skills reflect the quality of the material, as part of the classroom environment. In addition, the results match a study by Akdemir, Barin, and Demiroz (2012; see also Sim and Pop, 2016), which showed that a variety of material and activities in speaking classes increases students' satisfaction and promotes speaking practice in the class. Consequently, Mahbub-ul-Alam and Khan (2014) reported that developing linguistic skills, which only happens in class, is required to learn a language. 
This study illustrates the importance of analysing students' opinions within the teaching environment, as it provides the teacher and the institution with an insight to students' needs, which can then be reflected in the teaching process. Furthermore, the teacher plays a vital role in manipulating the classroom environment to accommodate the teaching process and thus encourage learning. As a result, teacher training is fundamental to establishing a well-educated and an effective facilitator of the teaching process (Sim \& Pop, 2016). Based on the importance of the teachers' role in achieving student satisfaction, a teacher might consider implementing different activities to promote student engagement. Moreover, proper evaluation and corrective feedback could be applied to reflect students' performance.

This study has certain limitations as it only investigates female students, further studies may be implemented on males of the same age group. Moreover, researchers may think about adding student achievement in speaking skills and correlate it with the variables provided in this study. Additionally, student satisfaction with the teaching process for the three other skills could be examined in future studies.

\section{Conclusion}

This study attempted to investigate EFL student satisfaction with acquired speaking skills in relation to the material and teacher. The findings illustrate the students' high satisfaction level with speaking skills and reveal a significant correlation between speaking skills with the material, and speaking skills with the teacher. Therefore, the current study suggests that measuring students' opinions on acquired speaking skills in relation to the teaching process and classroom environment may be effective for ensuring that the best quality of teaching is delivered to students, as satisfaction levels reflect improvement in communication and speaking skills.

\section{References}

Akdemir, A. S., Barin, M., \& Demiroz, H. (2012). Broadsheet English: Teaching speaking through newspaper articles. Procedia-Social and Behavioral Sciences, 46, 3967-3971. https://doi.org/10.1016/j.sbspro.2012.06.180

Asakereh, A., \& Dehghannezhad, M. (2015). Student satisfaction with EFL speaking classes: Relating speaking self-efficacy and skills achievement. Issues in Educational Research, 25(4), 345-363.

Bergil, A. S. (2016). The influence of willingness to communicate on overall speaking skills among EFL $\begin{array}{lllll}\text { learners. Procedia-Social and Behavioral } & \text { Sciences, } & \text { 232, }\end{array}$ https://doi.org/10.1016/j.sbspro.2016.10.043

Bolliger, D. U., \& Martindale, T. (2004). Key factors for determining student satisfaction in online courses. International Journal on E-learning, 3(1), 61-68.

Booker, Q. E., \& Rebman, C. E. (2005). E-student retention: Factors affecting customer loyalty for online program success. Issues in Information Systems, 6(1), 183-189.

Brown, H. D. (1994). Teaching by principles: an interactive approach to language pedagogy. Englewood Cliffs, NJ: Prentice Hall Regents.

Espinel, J. N. P., \& Canaría, D. C. F. (2010). How public high school students assume cooperative roles to develop their EFL speaking skills. HOW Journal, 17(1), 31-56.

Ghani, M., Nawaz, S., \& Asif, M. (2015). Developing speaking skills through sensory activities: An empirical study conducted on Pakistani EFL learners. Journal of Educational Research, 18(2), 84.

Jones, A. C. (2008). The effects of out-of-class support on student satisfaction and motivation to learn. Communication Education, 57(3), 373-388. https://doi.org/10.1080/03634520801968830

Mahbub-ul-Alam, A., \& Khan, M. E. I. (2014). Speaking in a second language in Bangladesh. NU Journal of Humanities, Social Sciences \& Business Studies, 1(1), 135-142.

Moradi, Z., \& Talebi, S. H. (2014). The Effect of pre-speaking strategies instruction in strategic planning on Iranian EFL students' awareness as well as students' fluency and lexical resources in speaking. Procedia-Social and Behavioral Sciences, 98, 1224-1231. https://doi.org/10.1016/j.sbspro.2014.03.537

Nash, G., Crimmins, G., \& Oprescu, F. (2016). If first-year students are afraid of public speaking assessments what can teachers do to alleviate such anxiety? Assessment \& Evaluation in Higher Education, 41(4), 586-600. https://doi.org/10.1080/02602938.2015.1032212

Nunan. D. (1991). Language Teaching Methodology. UK: Prentice Hall International.

Oliver, R. L., Rust, R. T., \& Varki, S. (1997). Customer delight: foundations, findings, and managerial insight. 
Journal of Retailing, 73(3), 311-336. https://doi.org/10.1016/S0022-4359(97)90021-X

Peng, H. (2015). Learner perceptions of Chinese EFL college classroom environments. English Language Teaching, 9(1), 22. https://doi.org/10.5539/elt.v9n1p22

Pishghadam, R., Zabetipour, M., \& Aminzade, A. (2016). Examining emotions in English language learning classes: A case of EFL emotions. Issues in Educational Research, 26(3), 508-527.

Rashidi, N., \& Moghadam, M. (2014). The effect of teachers' beliefs and sense of self-efficacy on Iranian EFL learners' satisfaction and academic achievement. Tesl-Ej, 18(2), 2.

Sim, M. A., \& Pop, A. M. (2016). Teaching speaking skills. The Annals of the University of Oradea, 264.

Wu, W. C. V., Marek, M., \& Yen, L. L. (2012). Promotion of EFL student motivation, confidence, and satisfaction via a learning spiral, peer-scaffolding, and CMC. International Journal of Computer-Assisted Language Learning and Teaching (IJCALLT), 2(3), 54-75. https://doi.org/10.4018/ijcallt.2012070104

Wu, J. H., Tennyson, R. D., \& Hsia, T. L. (2010). A study of student satisfaction in a blended e-learning system environment. Computers \& Education, 55(1), 155-164. https://doi.org/10.1016/j.compedu.2009.12.012

Yurt, S. U., \& Aktas, E. (2016). The effects of peer tutoring on university students' success, speaking skills and speech self-efficacy in the effective and good speech course. Educational Research and Reviews, 11(11), 1035. https://doi.org/10.5897/ERR2016.2718

Zahoor-ul-Haq, Khurram, B. A., \& Bangash, A. K. (2017). Development of speaking skills through activity based learning at the elementary level. Eurasian Journal of Educational Research (EJER), (69).

\section{Appendix A}

Student satisfaction with acquired speaking skills, materials and teacher questionnaire

$\mathrm{VU}$ = very unsatisfactory; $\mathrm{U}$ = unsatisfactory; $\mathrm{N}=$ neutral; $\mathrm{S}$ = satisfactory; VS = very satisfactory

\begin{tabular}{|c|c|c|c|c|c|c|c|}
\hline & & How satisfactory do you find & VU & $\mathrm{U}$ & $\mathrm{N}$ & $\mathrm{S}$ & $\mathrm{VS}$ \\
\hline & 1 & The spoken vocabulary you learn in your speaking class & & & & & \\
\hline$\stackrel{0}{\mathscr{U}}$ & 2 & $\begin{array}{l}\text { The effect of your speaking class on the improvement of your } \\
\text { pronunciation }\end{array}$ & & & & & \\
\hline$\stackrel{\equiv}{.0}$ & 3 & $\begin{array}{l}\text { The effect of your speaking class on the improvement of your fluency in } \\
\text { speaking }\end{array}$ & & & & & \\
\hline & 4 & $\begin{array}{l}\text { Your ability to make use of the stuff you have learnt in the classroom for } \\
\text { real life communication }\end{array}$ & & & & & \\
\hline & 5 & $\begin{array}{l}\text { Your speaking class in providing the opportunity for you to speak in } \\
\text { English with your classmates and instructors }\end{array}$ & & & & & \\
\hline & 6 & The level of the course book introduced to you & & & & & \\
\hline 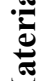 & 7 & $\begin{array}{l}\text { The contribution of your speaking class to the improvement of your } \\
\text { weaknesses in speaking skills }\end{array}$ & & & & & \\
\hline$z$ & 8 & $\begin{array}{l}\text { The speaking activities you are asked to do by your instructor in the } \\
\text { classroom }\end{array}$ & & & & & \\
\hline & 9 & The topic your instructor presents in the classroom for discussion & & & & & \\
\hline & 10 & Your instructor's motivation for teaching & & & & & \\
\hline & 11 & $\begin{array}{l}\text { The help of your instructor when you face speaking skills problems in the } \\
\text { classroom }\end{array}$ & & & & & \\
\hline 窇 & 12 & The way your instructor evaluates your speaking skills & & & & & \\
\hline$\stackrel{\bar{E}}{\Xi}$ & 13 & $\begin{array}{l}\text { The way your instructor makes use of audio-visual facilities in the } \\
\text { classroom }\end{array}$ & & & & & \\
\hline & 14 & Your instructor's feedback on your mistakes & & & & & \\
\hline & 15 & The encouragement you get from your instructor to speak & & & & & \\
\hline
\end{tabular}




\section{Copyrights}

Copyright for this article is retained by the author(s), with first publication rights granted to the journal.

This is an open-access article distributed under the terms and conditions of the Creative Commons Attribution license (http://creativecommons.org/licenses/by/4.0/). 